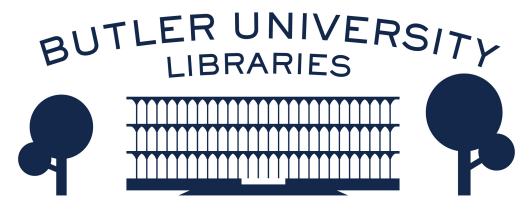

Journal of Hindu-Christian Studies

Volume 25

Article 12

November 2012

\title{
Announcement: Best Book in Hindu-Christian Studies
}

Follow this and additional works at: https://digitalcommons.butler.edu/jhcs

Part of the Religion Commons

\section{Recommended Citation}

(2012) "Announcement: Best Book in Hindu-Christian Studies," Journal of Hindu-Christian Studies: Vol. 25, Article 12.

Available at: https://doi.org/10.7825/2164-6279.1518

The Journal of Hindu-Christian Studies is a publication of the Society for Hindu-Christian Studies. The digital version is made available by Digital Commons @ Butler University. For questions about the Journal or the Society, please contact cbauman@butler.edu. For more information about Digital Commons @ Butler University, please contact digitalscholarship@butler.edu. 


\section{ANNOUNCEMENT: BEST BOOK IN HINDU-CHRISTIAN STUDIES}

THE Society for Hindu-Christian Studies announces Dualities: A Theology of Difference (Westminster John Knox Press, 2010) by Michelle Voss Roberts as the winner of its award, "Best Book in Hindu-Christian Studies-Theology and Philosophy (2008-2011)."

In her book, Michelle Voss Roberts brings together Mechthild of Magdeburg (thirteenth century Christian mystic) and Lalleśwarī (fourteenth century Kashmiri Śaiva poet) in order to reconfigure central Western binaries as dualities in relation. Drawing on elemental metaphors of fluidity in both women's work, Voss Roberts develops a feminist comparative theology that holds onto multiplicity without falling into dualism.

The Society held a panel on the book at its 2010 annual meeting in Atlanta, Georgia. Panel participants noted Voss Roberts's innovative approach and compelling constructive theology in light of her comparison. For a published version of the panel, see Journal of HinduChristian Studies 24 (2011).

Michelle Voss Roberts is Assistant Professor of Theology and Culture at Wake Forest University School of Divinity.

The Society congratulates Dr. Voss Roberts for her outstanding theological contribution to Hindu-Christian Studies.

"Best Book in Hindu-Christian Studies-Theology and Philosophy" celebrates a book that is: (1) a comparative study of a theme(s) in Hindu and Christian traditions or of two (or more) thinkers from those traditions; or (2) a work which traces some aspect of the philosophical or theological interaction between Hindus and Christians; or (3) a study in which an author, belonging (religiously and/or culturally) to either the Hindu or the Christian tradition, reflexively undertakes a study of a concept, image, ritual, author, text, etc., from the other tradition, and thus brings it into dialogue with his or her own.

The Other Four Finalists:

Baby Krishna, Infant Christ: A Comparative Theology of Salvation by Kristin Johnston Largen (Maryknoll: Orbis Books, 2011). See the full review in this issue.

Beyond Compare: St. Francis de Sales and Sri Vedanta Desika on Loving Surrender to God by Francis X. Clooney. See below the abbreviated review. The full review appeared in the 2009 issue.

Comparative Theology and the Problem of Religious by Hugh Nicholson. See below the abbreviated review. The full review appeared in the 2011 issue.

The Rhythm of Being: The Gifford Lectures by Raimundo Panikkar. See below the abbreviated review. The full review appeared in the 2011 issue, with the reviewer mistakenly listed as Michael McDonald instead of Michael McLaughlin.

\section{Beyond Compare: St. Francis de Sales and Śri Vedānta Deśika on Loving Surrender to God. Francis X. Clooney, S.J. Washington, D.C.: Georgetown University Press, 2008, 271 + xiii pages.}

AT the core of Beyond Compare is a claim, borrowed from literary theorist Charles Altieri, that "manner matters," that literature transforms its readers not primarily "adjectivally," by directly introducing new values, ideas or courses of action, but "adverbally," by changing how we perceive our experience as a whole (133-39, 202). Extending this insight to his comparative reading of two "spiritual classics"-the Treatise on the Love of God by the early modern Catholic bishop Francis de Sales and the Essence of the Auspicious 
Three Mysteries of the fourteenth-century Śrivvaiṣnava teacher and commentator Vedānta Deśika-Clooney ably explores the potential of such interreligious study for affective transformation and ever-deepening surrender to God. Three chapters introduce the two works and compare them on questions of authorial intent, the use and limits of reasoned discourse, and the place of scripture on the path of personal conversion. Two subsequent chapters then turn our attention more directly to the act of surrender to God in these two traditions and the consequences of such surrender in a transformed life of faith. Always the skilled and attentive reader, Clooney candidly recognizes significant differences between the two texts and their traditions, and even the real possibility of failure in the comparative exercise. Yet, he also suggests that such failure, when it arises as a consequence of sustained reading, will actually intensify the practice of both spiritual classics, separately and together. "Now unsettled by both texts," he writes, "[the interreligious reader] comes closer to the precipice of a real act of loving surrender" (186). In making this claim, Clooney does not merely advance the comparative theological project initiated in many earlier works, including especially Seeing through Texts (1996). He also subtly sets the study of religion itself on a new footing, deeply informed by the visions of Deśika and de Sales. The book thus speaks effectively both to specialists in Hindu-Christian Studies and to a wider scholarly public.

Reid B. Locklin

St. Michael's College, University of Toronto

\section{Comparative Theology and the Problem of Religious Rivalry. Hugh Nicholson. New York: Oxford University Press, 2011,}

\section{0 pages.}

HUGH Nicholson believes comparative theology to be an undertheorized discipline. Nicholson's book attempts to address this problem by providing ethical and epistemological reflection on comparative theology and the problem of religious rivalry.

Nicholson is concerned that comparative theologians idealize their discipline as apolitical and innocent. Against this naïveté, Nicholson asserts that comparative theology, along with all theology, is a political endeavor. Indeed, comparative theology as a discipline is especially fraught with politics, as it necessarily invokes the power of oppositional identity. Failure to acknowledge the dangers inherent in such discourse risks real harm (ix-x). Oppositional identity necessitates an us-them worldview. More dangerously, that us-them worldview may become "naturalized," a process in which "we" are deemed natural and good, and "they" are deemed unnatural and evil.

Nicholson believes that theology can be denaturalized (de-essentialized) but not depoliticized. The process of denaturalization will promote respect and dynamism, but this process must be advanced politically. According to Nicholson, one of the most powerful methods of undercutting the ideological stabilization of identity (naturalization) is comparison (16). Comparison reveals held truths to be historical, constructed, and contingent, and comparison treats the other as an opportunity rather than a threat. It seeks intellectual stimulation through placing the familiar into novel, illuminating contexts, as does metaphor (200). The practice of comparison frees theological reflection from being habitual and automatic, thereby freeing its practitioners from determination by inherited tradition.

Such a penetrating analysis would be compromised were it not applied. To apply his theory, in Part II Nicholson compares Eckhart with Sankara, partly to deconstruct the East/West dichotomy that still persists in religious studies, and partly to rehabilitate Otto, who had succumbed to that very dichotomy. 
Nicholson's book is a pioneering contribution to the nascent field of fundamental comparative theology. In the years to come, it will help comparative theology to proceed with greater awareness, confidence, and charity.

Jon Paul Sydnor

Emmanuel College

\section{The Rhythm of Being: The Gifford Lectures. Raimon Panikkar. Maryknoll, N.Y.: Orbis, 2010, 550 pp.}

THIS book consists of an edited version of the Gifford Lectures of 1989 which Panikkar continued to elaborate in the years following. It brings forth additional work incorporating material from Christophany: The Fullness of Man (2004) and the Experience of God: Icons of Mystery (2006). Much of Panikkar's thought revolves around the meaning of metaphysical terms in various linguistic registers," homeomorphic equivalents" a s he calls them. His search for concepts ranges widely over Plato, Aristotle, Aquinas, Plotinus, Heraclitus, Kant, Hegel, and Heidegger as well as Shankara, Ramanuja, Abinavagupta, and others.The work reflects an impressive grasp of many deep and long standing questions such as the meaning of esse, of time, of becoming, of cosmos, of motion, of matter, and of consciousness.

These lectures do not engage traditional problems such as the way that Christology ties to Trinity, as in the classic problem of the hypostatic union, since Panikkar 's focus is on the cosmic Christ as a principle. His Trinitarian focus is not so much on the immanent Trinity as on the cosmotheandric reality that ties together all that is. He does not directly attach the problem of original sin or of the difference between nature and the supernatural, made famous by authors such as de Lubac in Surnaturel, but is aware of it (301). The careful reader will in fact see many problems that Panikkar references but strategically chooses not to pursue. There is not much engagement with recent versions of process theism such as the work of Catherine Keller.

The style of thinking is at times more associative than argumentative. In one place, he says that he is like a contemporary hunter gatherer "recollecting life" from the tremendous field of human experience. Life here means inspirations, visions, insights and aphorisms of the kind that will help us see with a "third eye". It is a rewarding journey.

Michael McLaughlin Saint Leo University 